\title{
Anti-Inflammatory and Antioxidant in Vitro Activities of Magnoliae Flos Ethanol Extract
}

\author{
Ju Ri Ham ${ }^{1}$, Kyeong Won Yun², and Mi-Kyung Lee ${ }^{3}$ \\ ${ }^{1}$ Mokpo Marine Food-Industry Research Center, Jeonnam 58621, Korea \\ ${ }^{2}$ Department of Oriental Medicine Resources and ${ }^{3}$ Department of Food and Nutrition, Sunchon National University, \\ Jeonnam 57922, Korea
}

\begin{abstract}
This study evaluated Magnoliea Flos ethanol extract (MFE) as a potential natural anti-inflammatory and antioxidant in lipopolysaccharide (LPS)-stimulated RAW 264.7 macrophages and in vitro antioxidant assays. MFE (10, 30, and $50 \mu \mathrm{g} / \mathrm{mL}$ ) dose-dependently inhibited LSP-induced nitric oxide production, which is mediated by down-regulating gene and protein expression of inducible nitric oxide synthase and cyclooxygenase- 2 . MFE also down-regulated both gene and protein expression of nuclear factor-kappa B and its downstream genes, such as tumor necrosis factor- $\alpha$ (TNF- $\alpha$ ) and interleukin-6 (IL-6), compared with vehicle-treated cells. As a result, MFE treatment of LPS-stimulated macrophages significantly suppressed release of pro-inflammatory cytokines, such as TNF- $\alpha$ and IL-6. The antioxidant in vitro test revealed 2,2-diphenyl-1-picrylhydrazyl and 2,2-azino-bis(3-ethylbenzothiazoline-6-sulfonic acid) radical scavenging activities of MFE $(0.25 \sim 5 \mathrm{mg} / \mathrm{mL})$ of $16.62 \%$ to $75.17 \%$ and $38.54 \%$ to $92.91 \%$, respectively. The ferric reducing antioxidant ability of MFE was $0.54 \mathrm{mM}$ to $2.14 \mathrm{mM}$. Overall, MFE exhibited antioxidant activity and an effective anti-inflammatory response in LPSstimulated macrophages, which is potentially valuable for application as a natural functional material.
\end{abstract}

Keywords: anti-inflammatory, antioxidants, Magnoliae Flos, RAW 264.7 macrophage

\section{INTRODUCTION}

Inflammation is one of the complex physiological protective responses to foreign organisms, such as pathogens, irritants, dust particles, and viruses (Arulselvan et al., 2016). In particular, macrophages have important roles in inducing inflammatory responses through secretion of several cytokines (Dung et al., 2009, Lee et al., 2011). Macrophages are activated by lipopolysaccharide (LPS), endotoxin isolated from Gram-negative bacteria, and released inflammatory cytokines, including tumor necrosis factor- $\alpha$ (TNF- $\alpha$ ) and interleukin-6 (IL-6) (Kanno et al., 2006). However, an excessive inflammatory response is associated with progression of various chronic diseases, including obesity, diabetes, inflammatory bowel disease, cancer, and cardiovascular disease (Esser et al., 2014). Therefore, inhibition of the inflammatory response is crucial for controlling various diseases, and efforts have been made to derive anti-inflammatory substances from natural sources (Van et al., 2009; Mueller et al., 2010).

Magnoliae Flos refers to the flower buds of Magnolia denudata, and is often known by its Chinese name "Xinyi" (Shen et al., 2008). Magnoliae Flos is commonly used to treat allergic rhinitis, asthma, sinusitis, and headache in China and Korea (Kim et al., 2008). It contains various bioactive compounds, such as lignans (magosalin, magnosalicin, magnone A, B, magnolin, eudesmin), essential oils ( $\alpha$-pinene, cineole, citral, eugenol, and capric acid), and alkaloids $[(-)$-coclaurine, (-)-N-methylcoclaurine, (+)-reticuline] (Yun and Kim, 2021). A previous study showed that a Magnoliae Flos methanol extract protected against glutamate-mediated oxidative stress in mouse hippocampal neuronal cells (Jung et al., 2018). Recently, Chen et al. (2020) suggested that Magnoliae Flos essential oil can act as an immunosuppressant because it suppressed cytokine (TNF- $\alpha$ ) production in LPS-stimulated dendritic cells. However, the anti-inflammatory impact of Magnoliae Flos ethanol extract (MFE) on LPS-stimulated macrophages is unclear. Therefore, this study evaluated the anti-inflammatory activity and underlying mechanism of MFE on LPS-stimulated RAW 264.7 macrophages, and measured the in vitro antioxidant activity of MFE. 


\section{MATERIALS AND METHODS}

\section{Preparation of MFE}

Magnoliae Flos was purchased from Dong-Bu Herbal Medicine (Suncheon, Korea). Magnoliae Flos (100 g) was mixed with $80 \%$ ethanol $(1.5 \mathrm{~L})$ and extracted three times at $55^{\circ} \mathrm{C}$ for $4 \mathrm{~h}$. The extract was filtered with a 0.2 $\mu \mathrm{m}$ syringe filter (Sartorius, Göttingen, Germany) and concentrated using a rotary evaporator (EYELA Rotary Evaporator N-1000; Tokyo Rikakikai Co., Ltd., Tokyo, Japan). To obtain a powder, the concentrate was dried in a freeze-dryer (Freeze Dryer PVTFD10R; ilShinBioBase Co., Ltd., Yangju, Korea), generating a powder yield of $11 \%$. The total polyphenol and flavonoid contents of MFE were $54.33 \pm 1.10 \mathrm{mg}$ gallic acid equivalents (GAE)/g and 16.84 $\pm 1.83 \mathrm{mg}$ rutin equivalents/g, respectively.

\section{Cell culture and cell viability assay}

The murine macrophage cell line RAW 264.7 (KCLB no. 40071; Korea Cell Line Bank, Seoul, Korea) was cultured in Dulbecco's modified Eagle medium (Gibco, Grand Island, NY, USA) with $10 \%(\mathrm{v} / \mathrm{v})$ fetal bovine serum (Gibco) and $1 \%$ antibiotic-antimycotic (Gibco) at $37^{\circ} \mathrm{C}$ in a humified incubator with an atmosphere of $5 \% \mathrm{CO}_{2}$.

To determine the effects of MFE on cell proliferation, cells were seeded at a density of $5 \times 10^{4}$ cells per well in a 96-well plate and incubated at $37^{\circ} \mathrm{C}$ for $16 \sim 24 \mathrm{~h}$. Cells were then treated with $1 \mu \mathrm{g} / \mathrm{mL}$ LPS (Sigma-Aldrich Co., St. Louis, MO, USA) and MFE (10, 30, or $50 \mu \mathrm{g} / \mathrm{mL})$, and incubated for $24 \mathrm{~h}$. Macrophage viability was determined by using a EZ-Cytox cell viability assay kit (DAEIL Lab Service Co., Ltd., Seoul, Korea) according to the manufacturer's instructions. Absorbance was measured using a microplate reader (VersaMax, Molecular Devices, San Jose, CA, USA).

\section{Nitric oxide assays}

Cells $\left(5 \times 10^{4}\right.$ cells/well $)$ were plated in a 96-well plate and incubated at $37^{\circ} \mathrm{C}$ for $16 \sim 24 \mathrm{~h}$, and treated with LPS $(1 \mu \mathrm{g} / \mathrm{mL})$ and MFE $(10,30$, or $50 \mu \mathrm{g} / \mathrm{mL})$ for $24 \mathrm{~h}$. Culture medium supernatants $(100 \mu \mathrm{L})$ were mixed with the same amount of Griess reagent [ $1 \%$ sulfanilamide : $0.1 \%$ naphtylenthylenediamine (1:1)] at room temperature for $10 \mathrm{~min}$. The absorbance was measured using a microplate reader (VersaMax, Molecular Devices).

\section{Pro-inflammatory cytokines}

Cells $\left(5 \times 10^{4}\right.$ cells/well) were seeded in a 96-well plate and incubated at $37^{\circ} \mathrm{C}$ for $16 \sim 24 \mathrm{~h}$, treated with LPS (1 $\mu \mathrm{g} / \mathrm{mL}$ ) and MFE $(10,30$, or $50 \mu \mathrm{g} / \mathrm{mL})$, and incubated for a further $24 \mathrm{~h}$. Cytokine content in the cell culture medium was quantified using a mouse Duoset enzymelinked immunosorbent assay, according to manufacturer's instructions (R\&D Systems Inc., Minneapolis, MN, USA).

\section{RNA isolation and real-time polymerase chain reaction} (PCR)

Cells were seeded at a density of $1 \times 10^{6}$ cells per well in a 6-well plate and incubated for $16 \sim 24 \mathrm{~h}$ at $37^{\circ} \mathrm{C}$, treated with LPS $(1 \mu \mathrm{g} / \mathrm{mL})$ and MFE $(10,30$, or $50 \mu \mathrm{g} / \mathrm{mL})$, and incubated for a further $24 \mathrm{~h}$. Total RNA was extracted from RAW 264.7 macrophage cells using Trizol reagent (Invitrogen Life Technologies, Grand Island, NY, USA). The absorbance of the isolated RNA was measured at $260 \mathrm{~nm}$ and $280 \mathrm{~nm}$ using a Nanodrop 1000 (Thermo Fisher Scientific, Waltham, MA, USA) and quantified. The ReverTra Ace qPCR RT master mix (Toyobo Co., Ltd., Osaka, Japan) was used to reverse-transcribe total RNA into cDNA.

mRNA expression was quantified using SYBR green PCR kits (Qiagen, Hilden, Germany) and a CFX96TM real-time system (Bio-Rad Laboratories Inc., Hercules, CA, USA). The primers used for each gene were as follows: cyclooxygenase-2 (COX-2) (forward/reverse: 5'AGCCCATTGAACCTGGACTG-3'/5'-ACCCAATCAGC GTTTCTCGT-3'); glyceraldehyde-3-phosphate dehydrogenase (GAPDH) (forward/reverse: 5'-AAGGTCATCCCA GAGCTGAA-3'/5'-CTGCTTCACCACCTTCTTGA-3'); IL-6 (forward/reverse: 5'-AGTCCTTCCTACCCCAATTTC C-3'/5'-TGGTCTTGGTCCTTAGCCAC-3'); inducible nitric oxide synthase (iNOS) (forward/reverse: 5'-AGAACG GAGAACGGAGAACG-3'/5'-GAAGAGAAACTTCCAGG GGCA-3'); nuclear factor kappa-B (NF-kB) (forward/reverse: 5'-GAAGTGAGAGAGTGAGCGAGAGAG-3'/5'CGGGTGGCGAAACCTCCTC-3'); TNF- $\alpha$ (forward/reverse: 5'-AAAGACACCATGAGCACAGAAAGC-3'/5'GCCACAAGCAGGAATGAGAAGAG-3'). After normalizing to expression of GAPDH, relative expression of the target transcripts were calculated. mRNA expression was calculated using the $2^{-\Delta \Delta \mathrm{C}_{\mathrm{T}}}$ method (Livak and Schmittgen, 2001).

\section{Western blot analysis}

Cells $\left(1 \times 10^{6}\right.$ cells/well $)$ were seeded in a 6-well plate and incubated at $37^{\circ} \mathrm{C}$ for $16 \sim 24 \mathrm{~h}$, treated with LPS (1 $\mu \mathrm{g} / \mathrm{mL})$ and MFE $(10,30$, or $50 \mu \mathrm{g} / \mathrm{mL})$, and incubated for a further $24 \mathrm{~h}$. At the end of the incubation period, cells were washed with phosphate buffered saline and lysed in lysis buffer for $3 \mathrm{~h}$. After lysis, cells were centrifuged at 13,000 rpm for $5 \mathrm{~min}$, and the supernatants were assessed using Western blots. Total protein concentrations were measured using the Bradford method (Bradford, 1976). Protein samples $(10 \mu \mathrm{g})$ were separated with $10 \%$ sodium dodecyl sulfate-polyacrylamide gel electrophoresis, and then transferred onto nitrocellulose membranes (Whatman, Dassel, Germany). Membranes were incubated overnight with antibodies against COX-2, iNOS, IL-6, and TNF- $\alpha$ (1:200; Santa Cruz Biotechnology Inc., Santa Cruz, CA, USA) and $\beta$-actin (1:2,000; Sigma- 
Aldrich Co.) at $4^{\circ} \mathrm{C}$, followed by anti-rabbit IgG secondary antibody (1:10,000; Cell Signaling Technology Inc., Danvers, MA, USA) for $2 \mathrm{~h}$. The protein bands were visualized by incubating membranes with enhanced chemiluminescence reagent (Santa Cruz Biotechnology Inc.) and assessed with a chemiluminescence image analyzer and quantified by densitometry analysis using the UVITEC Alliance Q9 advanced system (UVITEC, Cambridge, UK).

\section{2,2-Diphenyl-1-picrylhydrazyl (DPPH) radical scavenging assay}

DPPH radical scavenging activity was determined using the method of Anggraini et al. (2011), with modifications. Briefly, $200 \mathrm{mM}$ DPPH was dissolved in ethanol and MFE (dilution of different concentrations) or ascorbic acid mixed in equal amounts. Mixtures were incubated at room temperature for $30 \mathrm{~min}$ in the dark, and then absorbances were measured at $517 \mathrm{~nm}$ using a microplate reader (VersaMax, Molecular Devices). Radical scavenging activity was calculated using the following equation: scavenging activity $(\%)=\left[1-\left(\mathrm{A}_{0} / \mathrm{A}_{1}\right)\right] \times 100$, where $A_{0}=$ optical density (OD) of the blank control and $\mathrm{A}_{1}=\mathrm{OD}$ of the sample.

\section{2,2'-Azino-bis(3-ethylbenzothiazoline-6-sulfonic acid) (ABTS) radical scavenging assay}

ABTS radical scavenging activity was determined using the $\mathrm{ABTS}^{+}$method described by Pawlak at al. (2010). The ABTS radical solution and MFE (dilution of different concentrations) or ascorbic acid mixed in equal amounts. Mixtures were incubated in the dark at room temperature for $30 \mathrm{~min}$. After incubation, absorbances were measured at $734 \mathrm{~nm}$ in a microplate reader (VersaMax, Molecular Devices). Radical scavenging activity was calculated using the following equation: scavenging activity $(\%)=[1-$ $\left.\left(A_{0} / A_{1}\right)\right] \times 100$, where $A_{0}=O D$ of the blank control and $\mathrm{A}_{1}=\mathrm{OD}$ of the sample.

\section{Ferric reducing antioxidant power (FRAP) assay}

Reducing power was determined using the method described by Thaipong et al. (2006). FRAP reagents were prepared by mixing $300 \mathrm{mM}$ acetate buffer, $20 \mathrm{mM} \mathrm{FeCl}_{3}$ - $6 \mathrm{H}_{2} \mathrm{O}$ in $40 \mathrm{mM} \mathrm{HCl}$ and $10 \mathrm{mM}$ 2,4,6-trippyl-S triazine at a ratio of 10:1:1. Mixtures were incubated at $37^{\circ} \mathrm{C}$ for $30 \mathrm{~min}$, then FRAP solution and standard $\left(\mathrm{FeSO}_{4} \cdot 7 \mathrm{H}_{2} \mathrm{O}\right)$, MFE, or ascorbic acid were added and samples were incubated in the dark at $37^{\circ} \mathrm{C}$ for a further $30 \mathrm{~min}$. After incubation, absorbance was measured at $593 \mathrm{~nm}$ using a microplate reader (VersaMax, Molecular Devices).

\section{Statistical analysis}

All experiments were performed in independent triplicates, and results were presented as mean \pm standard er- ror values. The data were analyzed by performing oneway ANOVA followed by Tukey post hoc tests to determine significant differences between groups. Statistical significance was considered at $P<0.05$.

\section{RESULTS AND DISCUSSION}

\section{Anti-inflammatory response of MFE in LPS-stimulated RAW 264.7 macrophages}

In many clinical trials and experiments, infiltration of macrophage into sites of inflammation, including liver, adipose, pancreas, and muscle tissues, has been observed in subjects with obesity, diabetes, etc. (Esser et al., 2014). The present study examined the anti-inflammatory activity of MFE in LPS-stimulated macrophages. Herein, no cytotoxicity was detected at concentrations of up to 50 $\mu \mathrm{g} / \mathrm{mL}$ of MFE in RAW 264.7 macrophages (Fig. 1A). As a result of treating LPS $(1 \mu \mathrm{g} / \mathrm{mL})$-stimulated macrophage cells with MFE concentrations of 10,30 , or $50 \mu \mathrm{g} /$ $\mathrm{mL}$, nitric oxide (NO) production was significantly reduced by $19.2 \%, 50.5 \%$, and $71.9 \%$, respectively, compared to vehicle-treated cells (Fig. 1B). A previous study showed that a Magnolia sieboldii methanol extract (25 and $50 \mu \mathrm{g} / \mathrm{mL}$ ) inhibited NO production in a dose-dependent manner in LPS-treatment RAW 264.7 cells by $16.6 \%$ and $66.1 \%$, respectively (Oyungerel et al., 2013). This trend was similar to our results, although reduction of $\mathrm{NO}$ induced by MFE was more than that by the Magnolia sieboldii methanol extract at their low concentration.

$\mathrm{NO}$ is synthesized from oxygen and L-arginine by the action of iNOS. Prostaglandins generated by COX-2 is also an important inflammatory mediator (Moita et al., 2013). Increased iNOS and COX-2 levels are associated with various metabolic diseases (Moita et al., 2013). The results of the present study show that MFE dose-dependently down-regulates gene and protein expression of iNOS and COX-2, which were increased by LPS treatment (Fig. 1C and 1D). Previous studies have shown that phenolic compounds in traditional medicinal plants can ameliorate diseases caused by inflammation and oxidative stress (Wadsworth and Koop, 1999; Luthria, 2006). The MFE used in this study contained 54.33 $\pm \mathrm{mg} \mathrm{GAE/g}$ of polyphenol.

Both iNOS and COX-2 are tightly regulated by pro-inflammatory transcription factors, including NF- $\mathrm{kB}$ (Moita et al., 2013; Arulselvan et al., 2016). Therefore, we measured gene expression of NF- $\mathrm{KB}$ and found that MFE inhibited LPS-induced increases in NF- $\kappa B$ expression in a concentration-dependent manner (Fig. 2A). Furthermore, the current study showed that gene and protein expression of other factors downstream of NF- $\mathrm{KB}$, TNF- $\alpha$, and IL-6, were also significantly down-regulated by MFE treatment compared with vehicle treatment (Fig. 2B and 
A
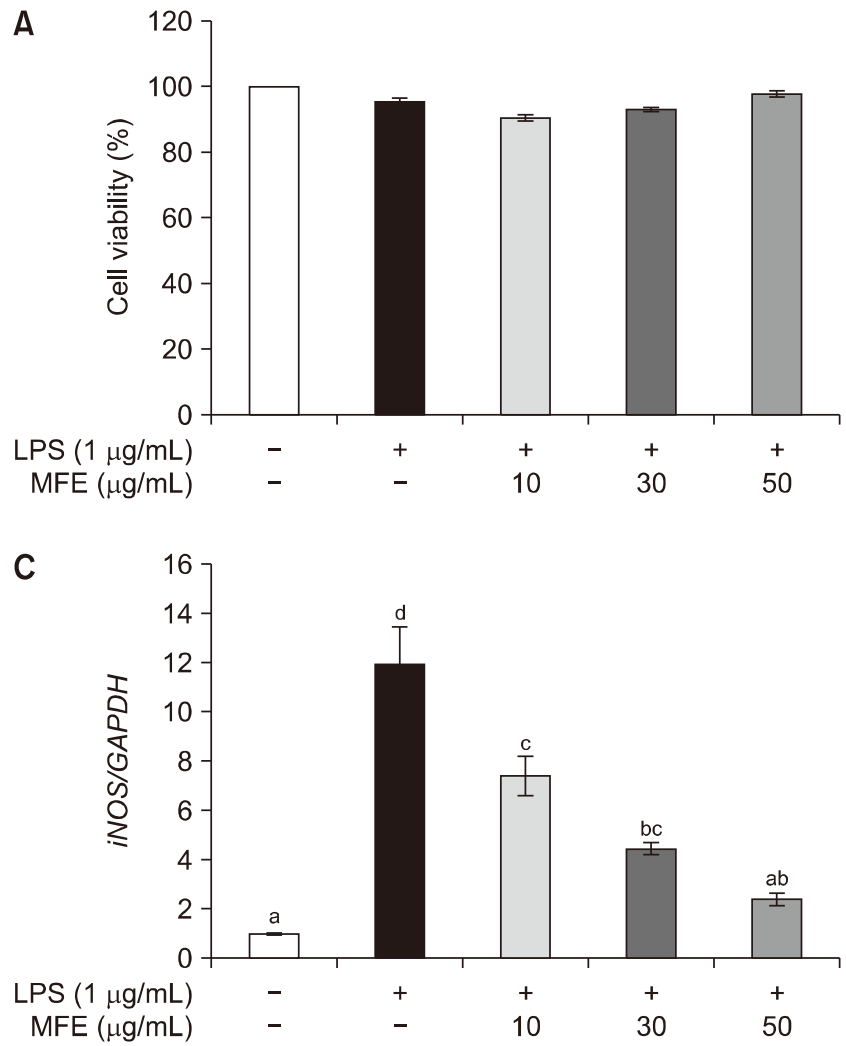

D

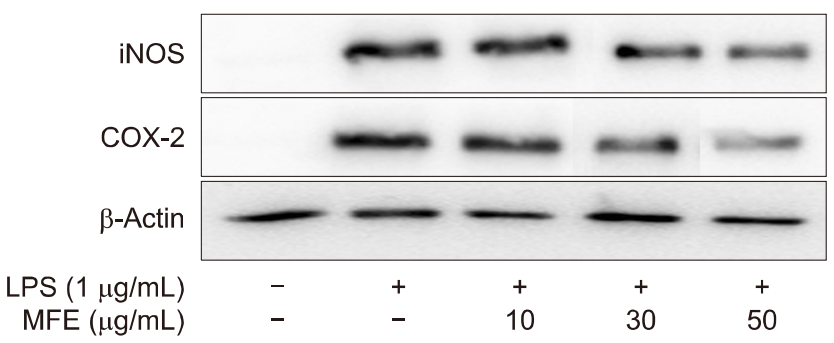

B
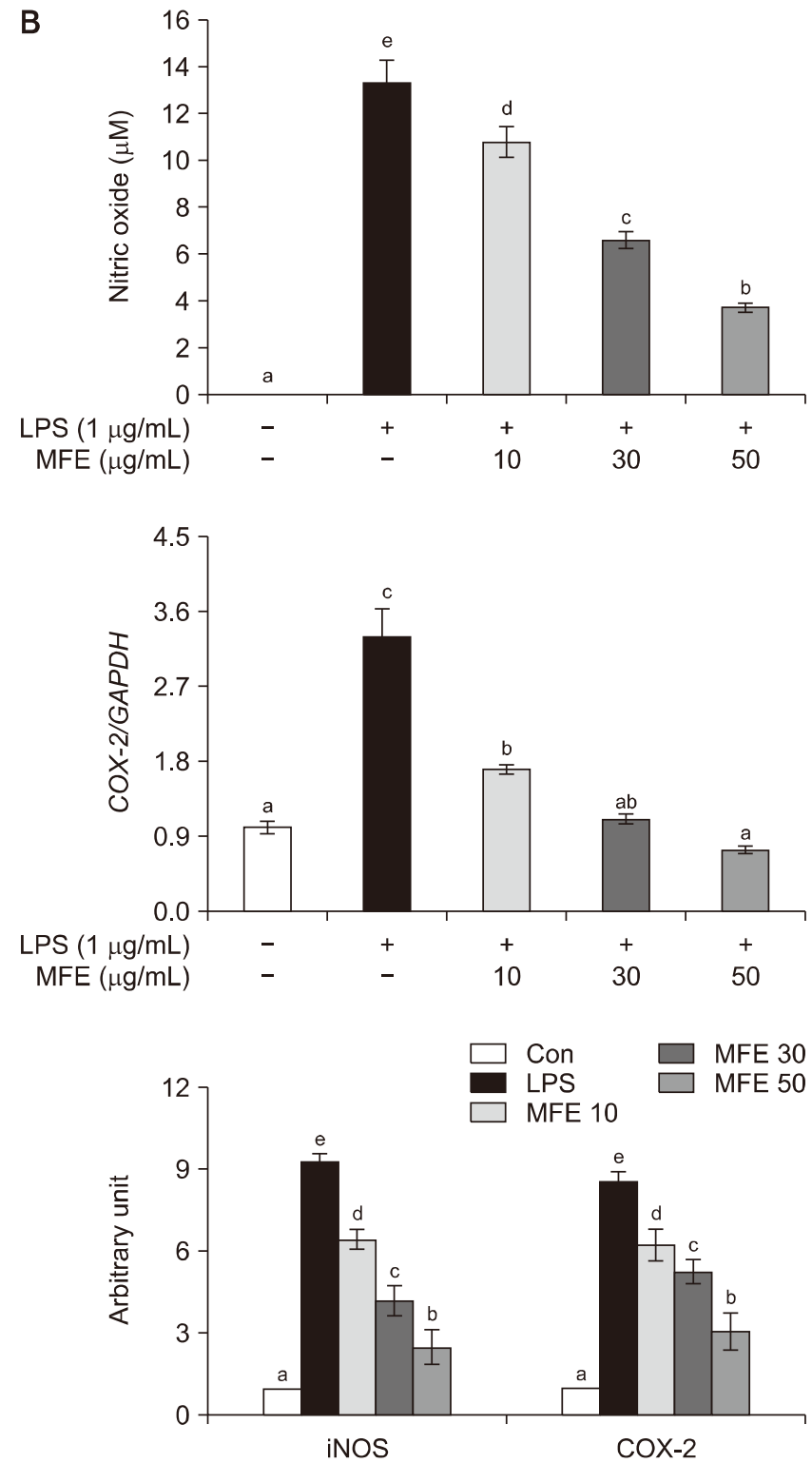

Fig. 1. Effects of MFE on cell viability (A), nitric oxide production (B), and iNOS and COX-2 gene (C), and protein expression (D) in LPS-stimulated RAW 264.7 macrophages. Data are presented as mean \pm standard error of three independent experiments. Values not sharing a common letter (a-e) significantly differ between groups $(P<0.05)$. Con, control; COX-2, cyclooxygenase-2; GAPDH, glyceraldehyde-3-phosphate dehydrogenase; iNOS, inducible nitric oxide synthase; LPS, lipopolysaccharide; MFE, Magnoliae Flos ethanol extract.

2C). These results led to decreasing TNF- $\alpha$ and IL- 6 levels from LPS-stimulated macrophages (Fig. 2D), since macrophages activated by LPS release pro-inflammatory cytokines, such as TNF- $\alpha$, IL-6, and IL-1 $\beta$ (Arango Duque and Descoteaux, 2014). Thus, MFE effectively inhibits LPS-induced inflammation via suppression of iNOS, COX2 , TNF- $\alpha$, and IL- 6 protein expression.

\section{In vitro antioxidant activity of MFE}

Overproduction of reactive oxygen species in an inflammatory site results in oxidative stress, which is related to various chronic and degenerative diseases, including cancer, diabetes, and coronary heart disease (Miliauskas et al., 2004; Whitton, 2007; Li et al., 2008). Previous studies have reported that phenolic and flavonoid compounds in plants exhibit antioxidant effects that can prevent many inflammatory diseases (Arulselvan et al., 2016). Therefore, we evaluated the antioxidant capacity of MFE by examining DPPH and ABTS radical scavenging activities and by performing FRAP assays. Free radical scavenging ability has an important role in preventing free radical-related damage in many diseases (Rahman et al., 2015). The present study showed that the DPPH and ABTS radical scavenging activities of MFE (0.25 5 mg/ $\mathrm{mL}$ ) were $16.6 \%$ to $75.2 \%$ and $38.5 \%$ to $92.9 \%$, respectively (Fig. 3A and 3B). DPPH radical scavenging activity assays are widely used to assess the hydrogen donation ability of bioactive compounds (Ajila et al., 2007), and 
A

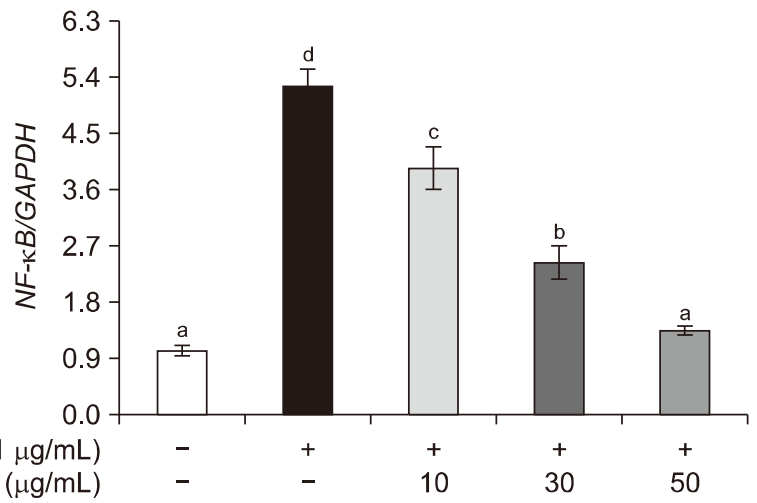

B

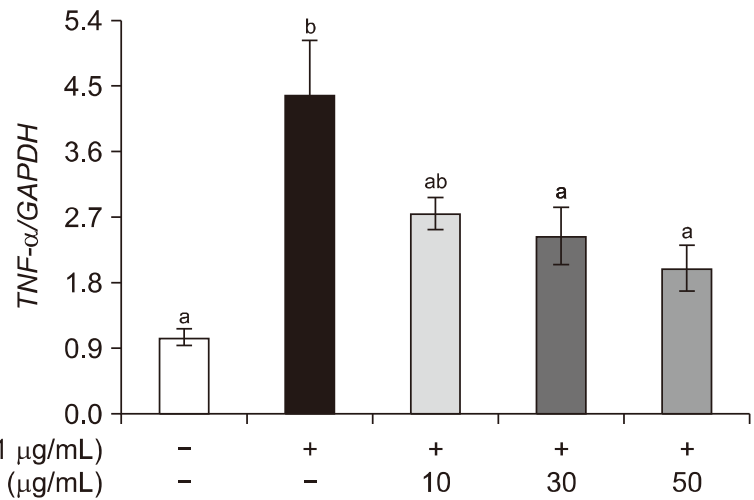

C

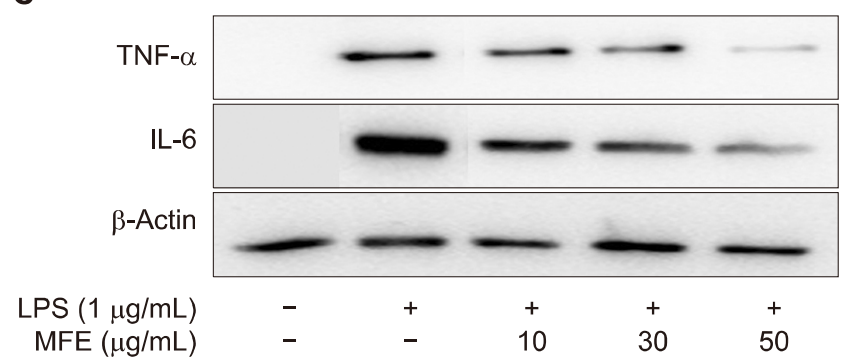

D



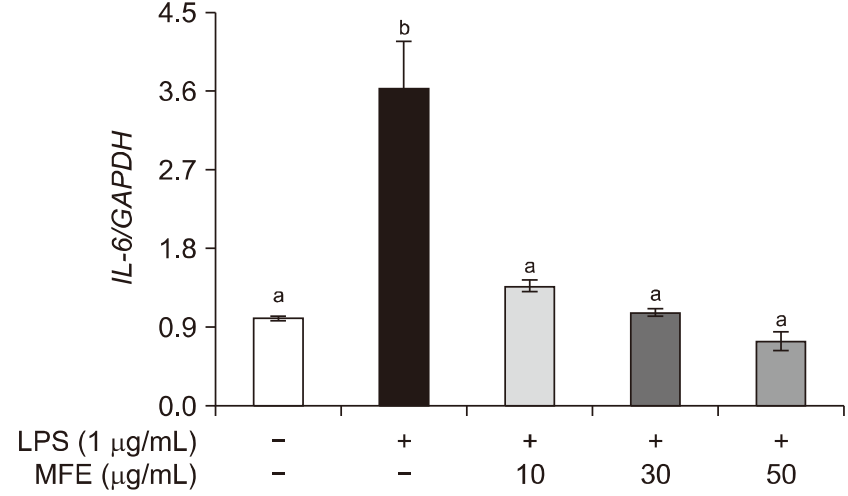
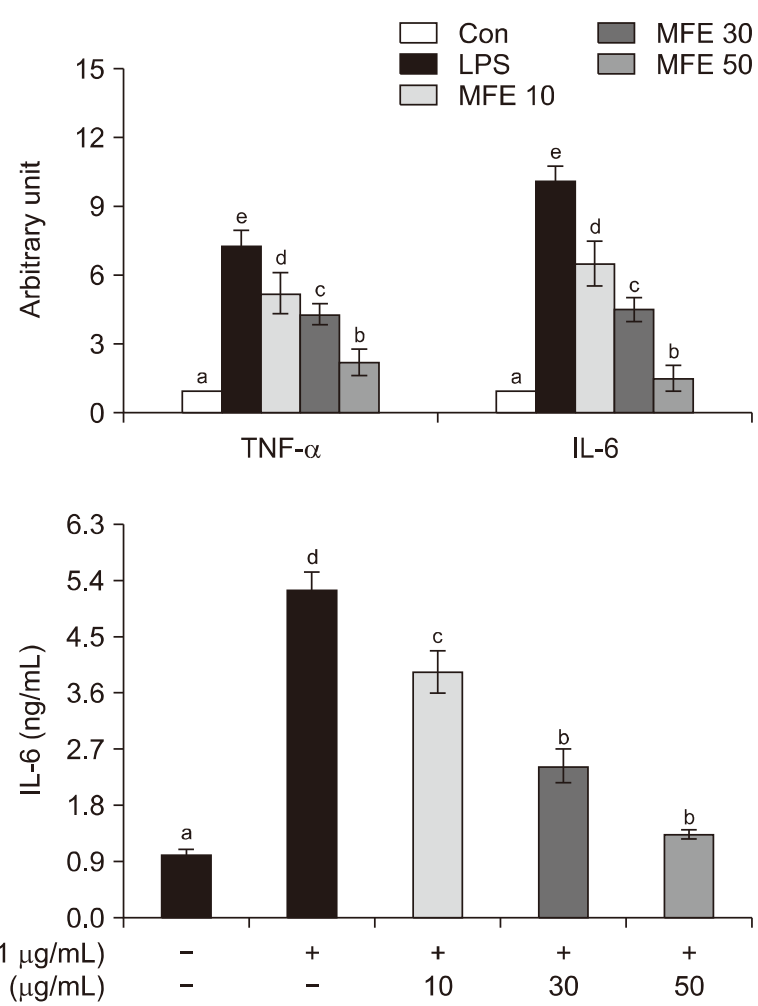

Fig. 2. Effects of MFE on NF- $k B$ gene expression (A), TNF- $\alpha$ and IL-6 genes (B) and protein expression (C), and levels of pro-inflammatory cytokines (D) in LPS-stimulated RAW 264.7 macrophages. Data are presented as mean \pm standard error of three independent experiments. Values not sharing a common letter (a-e) significantly differ between groups $(P<0.05)$. Con, control; GAPDH, glyceraldehyde-3-phosphate dehydrogenase; IL-6, interleukin-6; LPS, lipopolysaccharide; MFE, Magnoliae Flos ethanol extract; $\mathrm{NF}-\kappa \mathrm{B}$, nuclear factor-kappa B; TNF- $\alpha$, tumor necrosis factor- $\alpha$.

ABTS radical cation-based assays are one of the most commonly used antioxidant capacity assays (Fang, 2015). FRAP assay is also used to determine antioxidant activity, and their results positively correlate with those of DPPH and ABTS radical scavenging activity assays (Tian et al., 2021). In this study, FRAP activity of MFE was $0.55 \mathrm{mM}$ 


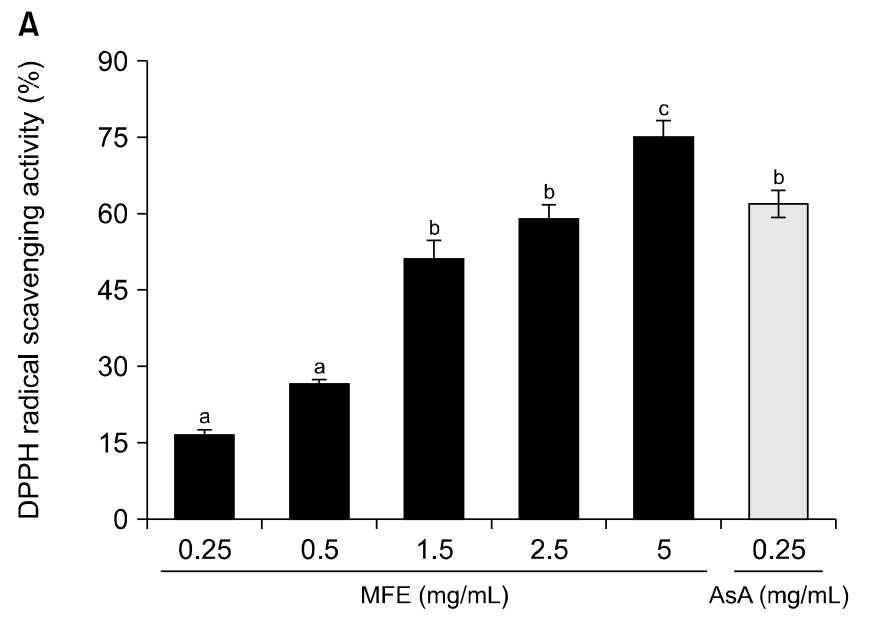

C



to $2.14 \mathrm{mM}$ (Fig. 3C), with higher concentrations of MFE having a higher antioxidant capacity, as evidenced by the DPPH and ABTS radical scavenging assays. A previous study showed that the DPPH radical scavenging activity of a fermented Magnoliae Flos extract was higher than that of a non-fermented Magnolia extract, a result which is related to the increasing polyphenol and flavonoid contents of the fermented extract (Park et al., 2015). In this study, the total polyphenol and flavonoid contents of MFE were 54.33 $\pm 1.10 \mathrm{mg}$ GAE/g and $16.84 \pm 1.83 \mathrm{mg} \mathrm{ru}-$ tin equivalents/g, respectively. Seo (2010) isolated several bioactive compounds, such as eudesmin, magnolin, epimagnolin A, fargesin, and lignin from Magnoliea Flos. However, the major constituents of MFE are not reported. In future studies, it would be helpful to identify the important active ingredients of MFE and their related mechanisms in vitro and in vivo.

In conclusion, MFE exhibited anti-inflammatory activity in LPS-stimulated RAW 264.7 macrophages via suppressing production of $\mathrm{NO}$ and release of pro-inflammatory cytokines (TNF- $\alpha$ and IL-6). Furthermore, MFE treatment effectively removed DPPH and ABTS radicals and had a high FRAP value. These results suggest that MFE could be used as a functional anti-inflammatory and antioxidant.

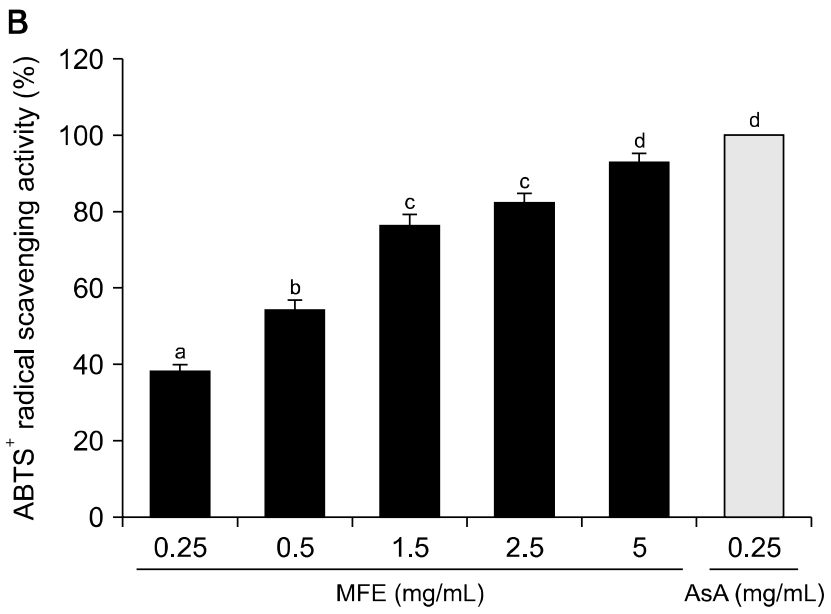

Fig. 3. Effects of MFE on DPPH (A) and ABTS (B) scavenging activities, and ferric reducing antioxidant power activity (C). Data are presented as mean \pm standard error values of three independent experiments. Values not sharing a common letter (a-e) significantly differ between groups $(P<0.05)$. ABTS, 2,2azino-bis(3-ethylbenzothiazoline-6-sulfonic acid); AsA, ascorbic acid; DPPH, 2,2-diphenyl-1-picrylhydrazyl; MFE, Magnoliae Flos ethanol extract.

\section{AUTHOR DISCLOSURE STATEMENT}

The authors declare no conflict of interest.

\section{REFERENCES}

Ajila CM, Naidu KA, Bhat SG, Prasada Rao UJS. Bioactive compounds and antioxidant potential of mango peel extract. Food Chem. 2007. 105:982-988.

Anggraini T, Tai A, Yoshino T, Itani T. Antioxidative activity and catechin content of four kinds of Uncaria gambir extracts from West Sumatra, Indonesia. Afr J Biochem Res. 2011. 5:33-38.

Arango Duque G, Descoteaux A. Macrophage cytokines: involvement in immunity and infectious diseases. Front Immunol. 2014. 5:491. https://doi.org/10.3389/fimmu.2014.00491

Arulselvan P, Fard MT, Tan WS, Gothai S, Fakurazi S, Norhaizan $\mathrm{ME}$, et al. Role of antioxidants and natural products in inflammation. Oxid Med Cell Longev. 2016. 2016:5276130. https:// doi.org/10.1155/2016/5276130

Bradford MM. A rapid and sensitive method for the quantitation of microgram quantities of protein utilizing the principle of protein-dye binding. Anal Biochem. 1976. 72:248-254.

Chen CH, Chen HC, Chang WT, Lee MS, Liu YC, Lin MK. Magnoliae Flos essential oil as an immunosuppressant in dendritic cell activation and contact hypersensitivity responses. Am J Chin Med. 2020. 48:597-613.

Dung NT, Bajpai VK, Yoon JI, Kang SC. Anti-inflammatory effects of essential oil isolated from the buds of Cleistocalyx operculatus (Roxb.) Merr and Perry. Food Chem Toxicol. 2009. 47:449- 
453.

Esser N, Legrand-Poels S, Piette J, Scheen AJ, Paquot N. Inflammation as a link between obesity, metabolic syndrome and type 2 diabetes. Diabetes Res Clin Pract. 2014. 105:141-150.

Fang J. Classification of fruits based on anthocyanin types and relevance to their health effects. Nutrition. 2015. 31:1301-1306.

Jung YS, Weon JB, Yang WS, Ryu G, Ma CJ. Neuroprotective effects of Magnoliae Flos extract in mouse hippocampal neuronal cells. Sci Rep 2018. 8:9693. https://doi.org/10.1038/s41598018-28055-z

Kanno S, Shouji A, Tomizawa A, Hiura T, Osanai Y, Ujibe M, et al. Inhibitory effect of naringin on lipopolysaccharide (LPS)-induced endotoxin shock in mice and nitric oxide production in RAW 264.7 macrophages. Life Sci. 2006. 78:673-681.

Kim EK, Song MY, Kim IS, Moon WS, Ryu DG, So HS, et al. Beneficial effect of Flos Magnoliae extract on multiple low dose streptozotocin-induced type 1 diabetes development and cytokine-induced beta-cell damage. Int J Mol Med. 2008. 22:481488.

Lee MY, Lee JA, Seo CS, Ha H, Lee H, Son JK, et al. Anti-inflammatory activity of Angelica dahurica ethanolic extract on RAW 264.7 cells via upregulation of heme oxygenase-1. Food Chem Toxicol. 2011. 49:1047-1055.

Li HB, Wong CC, Cheng KW, Chen F. Antioxidant properties in vitro and total phenolic contents in methanol extracts from medicinal plants. LWT. 2008. 41:385-390.

Livak KJ, Schmittgen TD. Analysis of relative gene expression data using real-time quantitative PCR and the $2^{-\Delta \Delta \mathrm{C}_{\mathrm{T}}}$ method. Methods. 2001. 25:402-408.

Luthria DL. Significance of sample preparation in developing analytical methodologies for accurate estimation of bioactive compounds in functional foods. J Sci Food Agric. 2006. 86: 2266-2272.

Miliauskas G, Venskutonis PR, van Beek TA. Screening of radical scavenging activity of some medicinal and aromatic plant extracts. Food Chem. 2004. 85:231-237.

Moita E, Gil-Izquierdo A, Sousa C, Ferreres F, Silva LR, Valentão $P$, et al. Integrated analysis of COX-2 and iNOS derived inflammatory mediators in LPS-stimulated RAW macrophages preexposed to Echium plantagineum L. bee pollen extract. PLoS One. 2013. 8:e59131. https://doi.org/10.1371/journal.pone. 0059131

Mueller M, Hobiger S, Jungbauer A. Anti-inflammatory activity of extracts from fruits, herbs and spices. Food Chem. 2010. 122:987-996.
Oyungerel B, Lim H, Lee CH, Choi EH, Li GH, Choi KD. Anti-inflammatory effects of Magnolia sieboldii extract in lipopolysaccharide-stimulated RAW264.7 macrophages. Trop J Pharm Res. 2013. 12:913-918.

Park H, Kim HS, Eom SJ, Kim KT, Paik HD. Antioxidative and anticanceric activities of magnolia (Magnolia denudata) flower petal extract fermented by Pediococcus acidilactici KCCM 11614. Molecules. 2015. 20:12154-12165.

Pawlak K, Bylka W, Jazurek B, Matlawska I, Sikorska M, Manikowski $\mathrm{H}$, et al. Antioxidant activity of flavonoids of different polarity, assayed by modified ABTS cation radical decolorization and EPR technique. Acta Biol Crac Ser Bot. 2010. 52:97104.

Rahman MM, Islam MB, Biswas M, Khurshid Alam AH. In vitro antioxidant and free radical scavenging activity of different parts of Tabebuia pallida growing in Bangladesh. BMC Res Notes. 2015. 8:621. https://doi.org/10.1186/s13104-015-1618-6

Seo Y. Antioxidant activity of the chemical constituents from the flower buds of Magnolia denudata. Biotechnol Bioprocess Eng. 2010. 15:400-406.

Shen Y, Pang EC, Xue CC, Zhao ZZ, Lin JG, Li CG. Inhibitions of mast cell-derived histamine release by different Flos Magnoliae species in rat peritoneal mast cells. Phytomedicine. 2008. 15:808-814.

Thaipong K, Boonprakob U, Crosby K, Cisneros-Zevallos L, Byrne DH. Comparison of ABTS, DPPH, FRAP, and ORAC assays for estimating antioxidant activity from guava fruit extracts. J Food Compos Anal. 2006. 19:669-675.

Tian C, Liu X, Chang Y, Wang R, Lv T, Cui C, et al. Investigation of the anti-inflammatory and antioxidant activities of luteolin, kaempferol, apigenin and quercetin. South Afr J Bot. 2021. 137:257-264.

Van Q, Nayak BN, Reimer M, Jones PJ, Fulcher RG, Rempel CB. Anti-inflammatory effect of Inonotus obliquus, Polygala senega L., and Viburnum trilobum in a cell screening assay. J Ethnopharmacol. 2009. 125:487-493.

Wadsworth TL, Koop DR. Effects of the wine polyphenolics quercetin and resveratrol on pro-inflammatory cytokine expression in RAW 264.7 macrophages. Biochem Pharmacol. 1999. 57:941-949.

Whitton PS. Inflammation as a causative factor in the aetiology of Parkinson's disease. Br J Pharmacol. 2007. 150:963-976.

Yun KW, Kim M. Korean medicinal plants. Haejin Media, Seoul, Korea. 2021. p 13-19. 